\title{
Morning, Paramin
}

Derek Walcott, Peter Doig, and an Ekphrasis of Relation

\author{
Maria Cristina Fumagalli* \\ University of Essex \\ mcfuma@essex.ac.uk
}

\begin{abstract}
In Morning, Paramin (2016), $5^{1}$ new poems by Derek Walcott are in dialogue with $5^{1}$ paintings by Peter Doig. Walcott, also an accomplished painter, has often engaged with the visual arts, but this is the first volume in which every poem "cor-responds" to a painting, offering unique opportunities to examine Walcott's ekphrastic practices and the way in which they might offer alternatives to current paradigms. Rejecting the paradigm of a paragonal struggle for dominance, I will argue that Morning, Paramin is shaped by an ekphrasis of Relation (resonating with Glissant's poetics of Relation) in which the verbal and the visual interact in complex ways, exercising mutual reclaimings of agency and transformative dialogues that engender new composite works of art governed by a noncompetitive, nonexploitative approach; as otherness is reconfigured, the right to "opacity" is upheld, and each image and word contribute to a whole bigger than the sum of its parts.
\end{abstract}

\section{Keywords}

Derek Walcott - Peter Doig - Morning, Paramin - ekphrasis - Relation - otherness creolization

Morning, Paramin is a sustained dialogue between $5^{1}$ new poems by Derek Walcott, which appear on the verso pages of the collection, and $5^{1}$ paintings by the contemporary artist Peter Doig, which appear on the recto pages (Walcott

* I would like to thank the Leverhulme Trust for the Major Research Fellowship which is supporting my current project, a monograph provisionally entitled Derek Walcott's Painters which provides the overarching framework for this article.

(C) MARIA CRISTINA FUMAGALLI, 2018 | DOI:10.1163/22134360-09203002

This is an open access article distributed under the terms of the prevailing CC-BY-NC license at the time of publication. 
\& Doig 2016). Morning, Paramin is not the first collection of poems in which Walcott engages with the visual arts. In Another Life, his 1973 autobiography in verse, Walcott describes his apprenticeship as a painter with his friend Dunstan St. Omer in the workshop of the St. Lucian artist Harold Simmons. Unlike St. Omer, who became a distinguished painter and muralist, Walcott decided to become a poet. Yet, he never stopped painting and being interested in the visual arts: the jacket covers of most of his poetry collections are his own paintings, and he has designed costumes, sets, programs, posters, and painted characters for his plays; he has also worked as an arts critic for the Trinidad Guardian for many years.

Since the late 1980s, Walcott has had numerous solo exhibitions of his paintings, storyboards, and working sketches for his plays, and he has also collaborated with the painter and collagist Romare Bearden, ${ }^{1}$ and contributed the text for Francesco Clemente's catalog for A History of the Heart in Three Rainbows (Walcott \& Clemente 2009). Painters and paintings have played important roles in his plays: in The Last Carnival (1986), Jean-Antoine Watteau's Embarkation for Cythera (1717) is given center stage; in Walker (2002) the chorus pleads with Romare Bearden, Jacob Lawrence, and Horace Pippin to "bear" the "burden," "paint" the "pain," and "keep" the "innocence" of African-Americans; the 2011 production of Moon-Child (2012) at the American Academy of Rome and at the Lakeside Theatre, University of Essex, was complemented by projected images of artwork by Walcott and his artist son, Peter Walcott; Paul Gauguin's visit to Vincent van Gogh in Arles in 1888 is dramatized in Walcott's latest play, O Starry Starry Night (2014).

The frame of reference of many of Walcott's poems is enriched and complicated by his engagement with the work of prominent painters as diverse as Rembrandt van Rijn and Edward Hopper, and his poems often establish a creative dialogue with particular paintings or evoke particular painters' use of the color palette, perspective, tonal quality, light and shadows, and, more broadly, a specific "way of seeing" which combines aesthetics and politics and which he reinterprets from his own standpoint. The long poem Tiepolo's Hound (2000), which, in its hardbound edition, includes 26 of Walcott's own paintings, features Walcott's fictionalization of the life of the Impressionist Camille Pissarro,

1 In 1983, the Limited Editions Club in New York published The Caribbean Poetry of Derek Walcott \& the Art of Romare Bearden, in which Bearden responds to a selection of Walcott's poems with a series of monoprints. The two artists knew each other personally, but Walcott was not involved in the selection of the poems (Price \& Price 2006:77-78). In 1979, Walcott used a collage by Bearden titled The Sea Nymph (1977) for the cover of his The Star Apple Kingdom (1979b). 
and is interspersed with references to works by (amongst others) Gianbattista Tiepolo, Paolo Veronese, Paul Cézanne, Paul Gauguin, and J.M.W. Turner, for which he also offers his own ekphrastic readings.

Walcott's substantial contribution to what Heffernan (1993) has called "the museum of words" has been routinely overlooked by scholars focused on the aesthetics of ekphrasis, because they do not tend to engage with Caribbean culture and art. Walcott's scholars, instead, have proposed a multiplicity of interpretations for the numerous ekphrastic efforts that are scattered throughout Walcott's collections and plays, offering them as illustrative examples of issues as different as intertextuality and postcolonial rewriting (Döring 2002; Neumann 2016); the poet's interest in the "inextricability of life and art" (Hamner 2000); his exploration of "his own inscription, as a man of African descent, in the modern aesthetics that require Blackness as a constitutive Other" (Emery 2007); or as Walcott's way of "breaking down spatial and temporal binaries that ... bind Caribbean landscapes in hierarchical relations to European art" (Handley 2010). Morning, Paramin, however, is the first volume in which Walcott, in his own, original way but thoroughly and systematically, engages with ekphrasis (every single poem here "responds" to a painting) and, as such, provides a unique opportunity to examine more carefully Walcott's ekphrastic practices and the way in which they might offer important alternatives to current paradigms. I will argue, in fact, that Walcott rethinks ekphrasis as a relation, or rather, as a poetics of Relation in which, as the Martiniquan theorist Édouard Glissant has explained, "each and every identity is extended through a relationship with the other" (Glissant 1997:11).

Ekphrastic poems, broadly speaking, are poems "about" paintings, and the Oxford Classical Dictionary (1968) defines ekphrasis as "the rhetorical description of a work of art." "About" and "description," however, are fairly vague terms: practically speaking, for example, when does description end and narrative or interpretation begin? Does "about" simply refer to the subject of the painting? Is the subject of a painting only what we see? What if a poem is concerned with what is left out of the frame? Is a poem that focuses on the technique of a painting, its handling of shapes and colors, the discourses and counterdiscourses that it promotes or challenges, or the reactions it might trigger in viewers not "about" that painting? Overall, as we will see, Walcott's engagement with Doig's paintings in Morning, Paramin goes well beyond simple description, stretching "aboutness" to the limit, broadening the scope of the dialogue between images and words and, in the process, rethinking and reconfiguring ekphrasis itself.

Scholars agree that the first example of ekphrasis is to be found in the Iliad in Homer's description of the shield of Achilles: this has been defined 
as "notional" ekphrasis, since the shield, in fact, was never a real object in the first place, but the fruit of Homer's (whoever he was) imagination (Hollander 1995:3-91). Despite the fact that its origins go back so far in time, ekphrasis really owes its popularity to the much more recent creation of galleries and museums and to what Walter Benjamin has named "the age of mechanical reproduction" (Benjamin 1999), all of which have made paintings and works of art accessible to the public. More often than not, however, museums, galleries, and art books offer readers and viewers not only images, but words as well: curatorial commentary, art criticism, and art-historical annotations, for example, often accompany (and frame) viewers' understanding and experiences of paintings, sometimes shaping ekphrastic efforts as in, for example, John Ashbery's "Self-Portrait in a Convex Mirror," in which scholars and critics are explicitly referred to (Ashbery 1985:188-204).

Museums and art books repeatedly feature in Walcott's work, so it is not surprising that his approach to Doig's paintings has also been mediated by art books and museum exhibitions and the words that accompany them: the poet owned many publications on Doig's work and, even if, unlike Ashbery, he never openly refers to critics and curators, one could argue that sometimes Walcott builds on the background information they provide, indirectly engaging with their views (inflecting or contrasting them) and, more generally, that Morning, Paramin responds to the way in which Doig's paintings have been contextualized and arranged in exhibitions or catalogues. Walcott and Doig met in Trinidad a few years ago, where the painter, who was born in Edinburgh, currently lives, and the St. Lucian poet was visiting family. During the December 2016 book launch for Morning, Paramin in Port of Spain, Doig explained that Walcott also joined him at the Montreal Museum of Fine Arts for Doig's No Foreign Lands exhibition (January 25-June 8, 2014). No Foreign Lands displayed paintings reflecting Doig's peripatetic and cosmopolitan life and interestsfrom Canadian snowscapes and suburban houses to Trinidadian landscapes, seascapes, and urban scenes - and was shaped by the belief that, as one of the curators puts it in the opening essay of the catalogue, "no land" is "foreign to painting" (Aquin 2013:24), a belief that, incidentally, problematizes the notion of geographical and cultural "otherness" in a way that resonates in Morning, Paramin. Walcott must have found the Montreal experience inspiring: most of the works by Doig that appear in Morning, Paramin were exhibited there and, sometimes, galvanized by Doig's intensity of purpose and the way in which he returns, time and time again, to the same motif or subject, Walcott's poems speak to the paintings actually included in the collection as much as they do to the different variations of the same painting on display in the museum and/or grouped together in the exhibition's catalog. 
Over time, there has been no actual consensus on how ekphrasis conjugates the relationship between the visual and the verbal. Positing the existence of a "sisterly" bond linking the two arts, some have argued that ekphrastic poems make the "silent" works of visual art "speak out" (Hagstrum 1958:158 n.18) and that it is possible to arrive at a "verbal counterpart of an art object" (Krieger 1967:9). W.T.J. Mitchell has categorized this attitude as "ekphrastic hope" (the hope to substitute the visual with the verbal), which he distinguishes from "ekphrastic indifference," the acceptance that establishing such reciprocity is an enterprise doomed to failure. "Ekphrastic fear," instead, reframes any suggestion of reciprocity between the visual and the verbal as dangerous promiscuity, which should be prevented or, at least, policed. Both "ekphrastic hope" and "ekphrastic fear," however, are fueled, in different ways, by the presupposition of the ' "otherness' of visual representation from the standpoint of textuality," a presupposition that Mitchell insists also sustains wider power relations (predicated on, for example, class, race, coloniality, or gender), which tend to conjugate the "self" as "an active, speaking, seeing subject" and the "other" as "a passive, seen and (usually) silent object" (Mitchell 1994:151-57).

Mitchell's template, however, has its limitations. It is noteworthy that Walcott's ekphrasis of Relation is articulated from the perspective of someone who comes from a culture and a place that have been routinely "othered," silenced, and marginalized by dominant discourses that also, more often than not, theorize their agency away. As Glissant reminds us, however, "the Other is within us and affects how we evolve": what happened in the Caribbean, a place of (often violent) encounter, contact, exchange (or, according to purists, dangerous promiscuity), "can be summed up in the word creolization," a process that renders "obsolete" the opposition between "Same and the Other" because it insists instead that "the Other is within us and affects how we evolve" (Glissant 1997:27, 31). In a way, Morning, Paramin replicates the process at the core of Glissant's creolization: it does not subscribe to the fantasy of a "pure otherness" while, at the same time, it does not dilute difference in the name of a "transparency" that reduces rather than enhances identity. There is no passivity in Glissant's Relation (Glissant 1997:137) and, similarly, in Morning, Paramin the verbal and the visual are brought together as two agencies that actively participate in the creation of composite texts that are visual and verbal at the same time, and where each component's right to "opacity" and to not being reduced to an equally artificially constructed "same" is valued and respected (Glissant 1997:189). "Opacities," Glissant continues, "can coexist and converge, weaving fabrics" and, giving advice that we could profitably follow in our reading of the collection, "one must focus on the texture of the weave," here the poem/painting ensemble, "and not on the nature of its component" (Glissant 1997:19o). In 
the rest of this article, I will read Walcott's poems and Doig's paintings jointly in order to better understand the nature of this particular "weave" and the different patterned fabrics produced by the relation between the visual and the verbal in Morning, Paramin.

Currently, one of the most widely accepted definitions of ekphrasis is "verbal representation of visual representation" (Heffernan 1993:3), a definition that maintains the focus on the representational aspect of the visual work-and implied notions of verisimilitude, similarity, mimesis, and translatability for its verbal counterpart—but also the "otherness" of the visual vis-à-vis the verbal rather than positing the possibility of "extending," as Glissant would have it, the two elements (poem and painting) involved in the ekphrastic relation. From a different perspective, however, if ekphrasis is "verbal representation of visual representation," one might be tempted to refer to (at least some of) the poems in Morning, Paramin as the verbal representation of the visual representation of a visual representation since, as the catalog of the Montreal exhibition repeatedly points out, many of Doig's paintings derive from postcards found or photographs taken by the artist and collected over the years. Most of Walcott's poems, however, stage instead the dramatization of what Mitchell calls a "double consciousness" (Mitchell 2005:7) in the approach to paintings, a double consciousness that complicates Walcott's ekphrastic effort. For example, looking at Doig's Girl in White with Trees (2001-2), a painting based on a photograph in which a little girl in white appears, almost spectrally, amongst tree branches (Searle, Scott \& Grenier 2007:101), Walcott underlines the similarities between the girl up in the trees and the isolated woman alone and far from home depicted in yet another representation, namely Andrew Wyeth's Christina's World (1948), and openly acknowledges that Doig's picture is "nothing more than a painting" (Walcott \& Doig 2016:39). Yet, as he seems conscious of (and more than ready to admit) the difference between painted figures and real people, Walcott also describes Wyeth's Christina as an autonomous "breathing" being in control of her "own breath," and salutes the girl in Doig's painting as a powerful and, ultimately, benign, presence, or an "angel" (Walcott \& Doig 2016:39). ${ }^{2}$ In other words, whilst being aware that he is dealing with pictures of people or objects, representations, and signs, Walcott still reserves the right to behave as if the colors and lines on the canvas were not only the very

2 In his poem Walcott acknowledges that he had access to different "versions" of this painting: in Montreal he could see seven more "versions," while ten appear in the catalog for the Montreal exhibition - this repetition obviously made the image even more haunting and the girl more of a "presence" (Walcott \& Doig 2016:39; Werner 2013:124-27). 
thing or person they are representing, but also living, energetic, and vital presences or "vital signs" in themselves - what Mitchell calls "signs as living things, not merely signs for living things" (Mitchell 2005:6, emphasis in the original). In so doing, Walcott acknowledges their right to be agents.

Walcott is not unsophisticated or naïve: his decision to treat Doig's paintings as complex, living presences, which he interrogates and which, in their turns, interrogate, ambush, seduce, challenge, or comfort him, is as deliberate as is his choice to include Doig's paintings in the collection-an inclusion that, in itself, revisits some of the received notions of the purpose of ekphrasis. Gabriele Rippl has suggested that the verbal and the visual can both be present at the same time, albeit in ways that are very different from the ekphrastic relation established in Morning, Paramin-she offers the example of illustrated novels or emblems, where the visual and verbal appear as separate units, and of pattern poems like George Herbert's "Easter Wings," where they form instead a single unit. By and large, however, ekphrastic poems are traditionally understood as works that do away with the presence of the works of art they are concerned with (Rippl 2010:42): it is understood (or, indeed, hoped) that the visual must be conjured up by the verbal, which must make us see with the mind's eye, and "convert the transparency of its verbal medium into the physical solidity of the spatial arts" (Krieger 1967:107) whilst rendering explicit the story that the painting can only implicitly contain. This explains why ekphrasis has often been theorized, following Mitchell's argument in Iconology (1986), as an activity that is an "essentially paragonal ... struggle for dominance between the image and the word" (Heffernan 1993:1; italics in original) modeled on the tradition of "paragone" (from the Italian paragone, "comparison"), a rhetorical debate aimed at establishing the superiority of a form of art over the others (Hagstrum 1958:66-70).

The title of one of Walcott's poems, "Paragon," seems to indicate that he wants to engage with this idea of paragone. The poem is juxtaposed to Doig's Cricket Painting (Paragrand) (2006-12), which testifies to the popularity of cricket in Trinidad, a sport that has been strongly associated with the fight for independence; one could assume, prima facie, that Walcott might capitalize on Doig's choice of subject to further elaborate on the notion of a struggle for dominance. Doig's painting, however, does not represent a cricket match, but a group of friends playing beach cricket in Paragrand Bay, a location on the north coast of Trinidad that is also known as Paragon - other versions of the same painting, including one on display in Montreal, are in fact titled Paragon (Werner 2013:22-25). Walcott's substitution of the toponym Paragrand with Paragon, therefore, can be seen as an attempt to focus readers' minds on the "paragonal paradigm." 
In Doig's painting, the bowler (in the foreground) is trying very hard, but his effort does not seem to constitute a threat to the batsman, as testified by the relaxed demeanor of the fielder, who seems resigned to the fact that the ball thrown by the bowler will be intercepted by the batsman. Walcott ostensibly adheres to the ekphrastic mode of describing a painting, acknowledging, at the same time, Doig's Gauguinesque departure from realism ("the sand turns red"). The hinge around which Walcott's poem revolves - the abstract noun "vehemence," a word that opens the poem-is the subject of its first verb ("draws") and is then equated to "love." The vehemence that "draws a wedge" down the bowler's back describes the way in which the strenuous effort marks the body of the player, but it can also refer, simultaneously, to the vehemence with which the painter draws or renders this effort on the canvas: all-over design, in fact, is very visible in some parts of Doig's work. Likewise, the serpentine line of the waves that advance and retract on Doig's beach, trying "to catch / the calm joy of the figures" (Walcott \& Doig 2016:45, emphasis mine), can be seen as a representation of the artist's love for his subject: the way in which he is drawn toward what he is drawing, catching, or trying to catch what is going on between the players with his pen/brush. The recurrence of the word "vehemence"-which returns five times in thirteen lines-and the position the word occupies in these lines (from the beginning to the middle and then back to the beginning and the middle again) reminds one of the movement of the waves (both visually and aurally, through repetition), but also conveys the intensity of Walcott's love for his subject or the "drawing" power of Doig's painting, which influences the way in which Walcott, orchestrating verbal, aural, and visual, creates a new composite work that relies on a reciprocal (not paragonal) relation between words and images as well as on their reclaiming of reciprocal agency.

Stephen Cheeke pointed out in 2008 that it is not always true that a poet necessarily "harbours a wish to control or dominate the image-as-other or to overcome the differences between poem and painting" (Cheeke 2008:36); three years later, Anne Keefe argued that theoretical templates that take for granted a "fundamentally oppositional confrontation between verbal and visual" do not necessarily reflect the way in which contemporary poets practice ekphrasis: following the poet Sharon Dolin, Keefe reformulates ekphrasis as an "ecstatic embrace of verbal and visual," which also highlights their "mutual agency" rather than the "verbal taking on agency over the visual" (Keefe 2011:137, 135). In "Paragon," Walcott too seems keen to counter, in his own ways, the paragonal paradigm. Walcott's poem does not sing the praises of a winner: significantly, he highlights that none of the players is a "paragon" of skills-one appears to be a disastrous bowler, the batsman thrives on the weakness of his opponent, the fielder does not move-but the poem celebrates instead the dedication 
of the players and the "calm joy" that playing brings to all of them. Walcott's paragon[e], therefore, does not seem to be concerned with establishing the superiority of one player or, more broadly, of one art or artist over the other: it highlights instead the importance of one's commitment to one's art and the delight that can come from engaging with the verbal and the visual at the same time-a delight that, as playwright, director, and designer, as well as painter and poet, he has repeatedly experienced and is experiencing in recording the visual/aural impact of the painting in this ekphrastic poem. If it appears to reject the paragonal paradigm, in fact, this poem and the collection as a whole also complicate a simplistic comparativist approach, which (like the paragonal one) seems to presuppose a neat separation between the verbal (poem) and the visual (painting). Morning, Paramin, in fact, highlights and makes the most of the possibilities offered by Doig's own ambivalence towards (but also delight with) the interplay of images and words.

Doig has declared that he considers his painting as "totally non-linguistic," that "there is no textual support" to what one "is seeing," and has argued that he is trying to create "something that it is difficult, if not impossible to put into words" (Doig 2007:124). At the same time, however, he has admitted that he "always wanted to make paintings that told stories and suggested things" (Hudson 2013), and his stories are sometimes generated by the interaction of the image he paints and his choice of title. In Doig's Hitch-Hiker, for example, a truck travels through a gloomy, fairly abstract and basic evening landscape with an empty field in the foreground, woods in the distance, mountains on the horizon, a sky full of clouds and rain. The truck is detailed but the titular hitchhiker is nowhere to be seen. ${ }^{3}$ As there seems to be no connection between what we see (the landscape with truck) and what the title urges us to look for (the hitchhiker), it is plausible that breaking the chain of referentiality was part of Doig's aim at the time, namely to create a narrative open to interpretation, particularly by extending the picture "away from and beyond the edges of the canvas" (Doig 2015-16).

Aptly, the poem Walcott juxtaposes to Hitch-Hiker (and which shares its title with it) takes up that challenge as its narrative continues outside the boundaries of what is reproduced in the painting and into discourse, stretching it not only in a geographical, but also in a geopolitical sense: it details an imagined journey during which the truck passes towns, grazing fields, innumerable barns and silos, creeks, and Indian Nations that have been "erased" (Walcott \& Doig

3 Unless we assume that the figure we barely see through the window is not the driver but the hitchhiker. 
2016:15). Echoing the drama created by the disconnection of image and title in the painting, the poem comes full circle with the title only in its last line, when it suddenly mentions the hitchhiker, who will be asleep all night on the freight of the truck. The hitchhiker's irruption in the poem reconnects the referentiality cable between title and work, but only at the last minute when, reproducing the effect that the title of Doig's painting has on us, we are invited to ponder on the hitchhiker's relationship to the landscape, to reinterpret the poem by going back to it and beyond the limits of what is on the page, and imagine new stories with the hitchhiker at their core, which might interrogate the very conditions of freedom and dispossession, mobility and erasure, inscribed in Walcott's landscaping.

Walcott is clearly fascinated by the possibilities afforded by Doig's open narratives: as Doig himself has explained, Walcott's "way of looking at" his paintings "was very much about looking for narrative-but not necessarily the narrative the painter may have put there" (Doig, quoted in Jelly-Shapiro 2017). Once a narrative is "found," Walcott builds on it, making the most of Doig's blending of figuration and abstraction and orchestrating, sometimes in unexpected ways, the verbal and visual. For example, in Doig's Night Palm (North Coast) (2008) the green leaves of the titular palm are only sketched, some areas of the canvas are left bare, the background is dark and light blue. Walcott's poem juxtaposed to this image is titled "Santa Cruz I" and contains no mention of palms or nighttime (Walcott \& Doig 2016:53). Walcott here reinterprets Doig's abstract wilderness as a battered landscape, undone by the destructive power of a tropical storm. Countering both "romanticization" and "tropicalization" of the Caribbean landscape (Thompson 2006:5-7), in describing a reality that is intensely local, the poem brings to the fore the social tensions and political responsibilities that exoticism tends to leave out of the frame: flooding is the most prevalent and persistent natural hazard affecting Trinidad, particularly its urban areas, mainly due to unplanned housing development, deforestation, and irresponsible agricultural practices. ${ }^{4}$ The reference to the razing to the ground of the city of Carthage by the Roman army adds further complexity, blurring the distinction between devastation caused by "natural" disasters and that caused by "unnatural" ones, those where human negligence or disre-

4 "Urban development has occurred at a rate beyond the physical planning capacities to mitigate flood impacts. Rapid growth in the absence of adequate physical planning measures has contributed to flood disasters as water blasts off buildings and various surfaces and overwhelms the drainage systems. Yet, inappropriate land use activities such as deforestation, unplanned and improper housing development and inappropriate agricultural practices, persist unchecked, resulting in a failure to mitigate flooding" (Udika 2010). 
gard for human lives and ecosystems plays a pivotal role (Abramovitz 2001). Walcott's poem and its narrative, therefore, are less inspired by what Doig's painting represents (a palm in the night) than by its kinetic energy and the way in which color is applied (or not) on the canvas.

Doig's partly figurative and partly abstract landscapes or his choice of saturated colors often create almost hallucinatory images or, as he himself has put it, "something that is somehow in between the actuality of a scene and something that is in your head" (Doig 2007:132). In J.M. at Paragon (2004), the first painting we encounter in Morning, Paramin, for example, the sky is bright red, the line of the horizon is yellow, the sea is brown (where the sand can be seen in transparency) and greyish/greenish with white and purple brushstrokes (where the water is deeper). Intricate tropical foliage and flowers on the top of the painting are superimposed on the red sky and recall the purple, green, and brown of the sea and beach. A tiny, bearded figure is plunged, up to his waist, in the foaming waters of Paragon Bay, and once this small, white figure, slightly off center, enters our gaze, it becomes impossible to disregard it, despite the fact that his identity is concealed/revealed to us by the title, which, while anchoring him in the landscape, only offers initials (J.M.). ${ }^{5}$ In Walcott's poem, "Dedication to S.H.," Doig is present in the poem: Walcott addresses the painter directly, as if he were in front of him, and invites him to "share," for the first time, his St. Lucian home and the St. Lucian landscape. Walcott does not describe (or refer to) Doig's painting, suggesting from the very beginning that, in his ekphrastic efforts, he does not necessarily have to "represent" the paintings his poems are in dialogue with; at the same time, it is evident that the poem has been molded by Doig's visual—but also, as we will see, verbal—choices.

Walcott's own hallucinatory landscaping moves between geographical locations (the toponym Blanchisseuse is the name of a location in both Walcott's St. Lucia and in Doig's Trinidad), but also between present and past in its simultaneous inventory of the actual view from his balcony to the evocation of the remembered landscape of Walcott's youth, "those scenes" he "knew" in his "green years" (Walcott \& Doig 2016:3). The past, however, is also made present in Walcott's title, "Dedication to S.H.," which, importantly, capitalizes on Doig's use of initials in his own title. It is easy to guess that Walcott's initials S.H. stand for Walcott's late friend and fellow poet Seamus Heaney, who used to be a regular guest at Walcott's house in St. Lucia even if, unlike Doig, Heaney is never mentioned in this poem. The corresponding use of initials in the two titles, however, invites us to look for (and find) Heaney in Doig's painting, his

5 This figure has been identified as the German artist Jonathan Meese (Scott 2007:39). 
visual counterpart the small, ghostly white but impossible-to-ignore figure in the painter's half-actual, half-remembered landscape, highlighting, once again, that painting and poem are not locked in a paragonal struggle (the toponym Paragon actually figures also in this title), but participate in a collaborative relation.

Similarly, we are invited to ponder on the role of titles in Walcott's ekphrasis of Relation and, at the same time, to look for the lingering presence of Walcott's ex-wife Margaret, who died in 2014, in the painting, which is juxtaposed to the poem "In the Heart of Old San Juan." In this poem, Walcott remembers that on the day of Margaret's funeral in Port of Spain, the capital of Trinidad, even if she "was gone ... all the streets were hers" (Walcott \& Doig 2016:33). The painting by Doig with which the poem is in dialogue, The Heart of Old San Juan (1999), seems, at first, a rather odd choice, as it portrays an empty basketball field drawn from a photograph taken in San Juan de Puerto Rico (Werner 2013:96). Doig has added a crucial detail to this photo, namely a big painted board with a huge red heart situated on the roof of a small side building. This mysterious heart, peripheral in the visual composition but central in Doig's title, is therefore posited (literally) as the very heart of the place, much in the same way in which, in the poem, the late Margaret becomes the "heart" of Port of Spain for the bereaved Walcott, who feels as desolated as Doig's basketball field.

The connection between Margaret, the basketball field, the poem, and the heart can be better accounted for by the fact that, in Montreal, Walcott was able to see Doig's Study for the Heart of Old San Juan (1999), which appears in the catalogue with The Heart of Old San Juan (1999), both of which—include a female presence, namely the elusive silhouette of a woman on skates (Werner 2013:96). Furthermore, in the context of a collection in which Trinidad, as we will see, plays such a crucial role, Walcott's "Old San Juan" is less likely to be the capital of Puerto Rico of Doig's photograph than the San Juan in the outskirts of Port of Spain where Walcott also set part of The Joker of Seville (1978), his adaptation of Tirso de Molina's El Burlador de Sevilla (circa 1630). The geographical dislocation from Doig's San Juan de Puerto Rico to Walcott's Trinidad's San Juan recorded in the poem is not simply based on the fact that they share the same name, but is supported by visual correspondences that deepen the connection between poem and painting through a triangulation with Walcott's play. Walcott's drawings for the settings and his stage directions for The Joker of Seville, in fact, specify that the stage should be round to make it identifiable, equally, with Spanish bullfight and Trinidadian stick-fight or cockfight arenas, while the only large unit required is "a mobile ornamented box": the circles and rectangles so prominent in Doig's basketball court, therefore, find a visual counter- 
part in the circular shape and rectangular cuboid of Walcott's stage (Walcott 1979a:5).

As the visual and the verbal illuminate one another in unexpected ways, they also elucidate the otherwise unclear connection between title and poem and the small but all important alteration that Walcott includes in his title, namely the preposition "in," which turns Doig's "The Heart of Old San Juan" into Walcott's "In the Heart of Old San Juan." Since there is no "San Juan" in Tirso de Molina's original play, the village of San Juan might have been chosen by Walcott as a setting for the The Joker of Seville precisely because the toponym chimes with Don Juan, the name of the protagonist. If one substitutes San Juan with Don Juan in the poem's title, "In the Heart of Old Don Juan" might sound like a self-referential comment, as it was during the production of The Joker that premiered in 1974 at the Little Carib Theater of Port of Spain (which is actually mentioned in the poem) that Walcott first met Norline Metivier, the catalyst of his estrangement from Margaret (Walcott 1979a:6). It seems very clear, therefore, that at the time of writing this poem, in the heart of this, now elderly, Don Juan (Walcott) there was a lot of "regret" - a word that in the poem rhymes with "Margaret" - for the pain caused by his actions (Walcott \& Doig 2016:33). Once again, therefore, if considered together, poem and painting generate another new composite work where the visual and the verbal illuminate one another, reclaim mutual agency, and open up an interactive space in which the viewer can enter ("in" is a crucial preposition in the poem's title) and which he or she can fill in for himself/herself. This (at first sight improbable) combination, moreover, also turns on its head the traditional understanding of ekphrasis as an "obstetrical" verbal description of a painting that "delivers" the story that the painting contains but cannot fully represent (Heffernan 1993:5). Creative processes are always extremely complex — often chaotic - affairs and, as such, are very hard to pinpoint in an exact fashion, but here things seem to be going in the opposite direction, as it is only by taking on board Doig's painting that we might make explicit the story that Walcott's poem might implicitly contain, reaching beyond what is in front of our eyes into what might have been going on behind Walcott's eyes (or, indeed, in his "heart").

Morning, Paramin is interested in creative processes: with "Ski Jacket," while describing a snowscape, Walcott simultaneously illustrates the process of bringing into focus a vision and developing a narrative. Initially "direction is hard to find" on a snowy-white page or canvas, but slowly "things take definition" (Walcott \& Doig 2016:5). Aptly, in the 1994 painting by Doig with which the poem is paired — and with which it shares the same title - if one looks carefully, one can see tiny skiers trying to find their feet on a mountain slope. At least initially, therefore, the correspondence between poem and painting relies both 
on the winter landscape and the tentativeness they depict. The poem, however, departs from this shared subject to develop its own different (but related) narrative and, most importantly, it does so in a way that is reminiscent of how Doig's painting came about, a fact that reaffirms the agency of the visual and its influence on the verbal rather than establishing a relation where the verbal always takes over. SkiJacket was inspired by a photograph of a ski resort and is a split canvas that started out as one panel, the panel on the right; Doig then photographed what he had painted, turned the slides and projected the image, stretching it out and distorting it. As the panel on the left opens the original image out, blowing definition and changing directionality, the two sides rhyme, as do different words in the poem, which nevertheless correspond in sound; assembled together the two panels create a new image with a strong center focus out of which everything seems to originate (Doig 2015-16). The painting relies on a mirror image that does not, however, reflect exactly what it doubles and also cracks the mirror of natural resemblance, verisimilitude, and realism (without breaking it); the poem similarly refuses, in more than one way, to be reduced to an exercise in mirroring, verbally, what the painting represents.

Walcott acknowledges Doig's source as a "square and banal" postcard, or a postcard-like cliché (even kitsch) image, but he praises the painter for the way in which he transcends banality to arrive at the "simplicity" where, Walcott insists, "home is." This "simplicity" is defined, in the last line of the poem as "a leaf-flecked boulder, a leaf-chocked canal" (Walcott \& Doig 2016:5) creating a deep, if unexpected, connection between Doig's snowscape and Walcott's own "home," the St. Lucia that, as a youth, he swore never to leave until him and the late St Omer "had put down, in paint, in words ... all of its sunken, leafchoked ravines" (Walcott 2009:52). As the poem establishes itself as a work of art in its own right, as open to interpretation as the painting it is (obliquely) addressing, the way in which poem and painting relate to one another gives rise once again to a new composite work (both verbal and visual) in which correspondences and differences are concomitantly enhanced and which does not attempt to close, but actually thrives on, the gap between language and image (and between geographical locations) opened up by the combination.

Ultimately, all paintings and poems in Morning, Paramin are circumscribed by the whiteness of the page on which they are printed and from which they take definition, both individually and as an ensemble; it is precisely on this whiteness, which sets poems and paintings apart but also brings them together in the book, that creative negotiations between the sayable and the seeable and the interaction between two mutually shaping agencies (poem/poet and painting/painter) take place. Unlike illustrated books which aim to demonstrate that "it is possible to say 'this is that"' (Mitchell 1994:69-70) or to unproblemati- 
cally, exhaustively, and definitively designate and describe an image or a painting, Morning, Paramin choreographs instead an ekphrasis of Relation in which poems do not simply "translate" paintings (or vice versa), but productively combine with them in mutually transformative ways. The fact that paintings and poems often share the same title, as we have seen for "Ski Jacket"/Ski Jacket, even as it encourages us to see them as "one," does not imply the erasure of their own or their author's individuality. As Walcott establishes the coordinates of the world that poet and painter share, for example, he also reaffirms the boundaries behind which he is not prepared to follow the visual artist: in "Mal d'Estomac," humorously building on the connotations of the title of Doig's Mal d'Estomac (2008), a rather abstract rendition of the homonymous bay in northern Trinidad, Walcott openly declares not to be particularly fond of this work and makes it clear that Doig's interest in "difficult" modern abstract paintings makes him "nauseous" (Walcott \& Doig 2016:75). At the same time, when poems and paintings have different titles, they are not completely dissociated from one another: as we have seen with J.M. at Paragon/"Dedication to S.H.," The Heart of Old San Juan/“In the Heart of Old San Juan," and in Night Palm/"Santa Cruz I," the synergy between poem and painting creates a powerful new work, which highlights and thrives on a fruitful tension between words and images where the sayable and the seeable are not immediately explained by, or reduced to, one another. A change of title, moreover, often signposts that Walcott's interest does not reside in the painting's motifs or subject, but in the painting's creative process or in the mood or memories evoked, for example, by a certain color combination or the placement of visual elements in a painting.

In the poem "The Tanker," Walcott's words are juxtaposed to an untitled painting by Doig (Untitled, 2008) featuring a bottle of beer, a nineteenthcentury locomotive, and a boat partly hidden behind the bottle, seemingly springing out from it. In his poem Walcott makes no direct reference to the painting but describes instead a scene engulfed in silence with two different focal points: a tanker, motionless on the horizon, and a heron, perfectly still on the branch of a tree on a beach at noon (Walcott \& Doig 2016:81). Yet, the way in which the painting organizes space works as a blueprint for the poem: if the painting were to be simplified to three main lines (one horizontal and one vertical with a shorter line springing up from it), the horizontal line would be the locomotive which would correspond, in the poem, to the tanker; the vertical and shorter lines would represent instead the bottle and boat, which would find their counterpart in the poem's tree with heron. The fact that the painting is untitled facilitates the poet's decision to focus on shape and composition, a consideration that highlights, indirectly, how words can affect our understanding of paintings. The poem, however, investigates the relationship 
between visual and verbal, image and words, by foregrounding the importance of silence for both arts and by recasting it as an empowering tool.

Walcott describes his standpoint (the balcony from which he observes tanker, heron, and tree) as the "perfect place" to share with his painter-friend, going as far as offering this view to him as a potential subject for a painting because of Doig's ability to "hallow silence" (Walcott \& Doig 2016:81). "Great painting," the poem goes on to explain, is "beauty without speech" (Walcott \& Doig 2016:81). The definition of "painting as silent poetry" attributed to Simonides of Keos-who, congruently, also defined poetry as a "speaking picture" - was later deployed, in conjunction with the well-known Horatian simile ut pictura poesis ("as is poetry so is painting"), to lay the ground for the presupposition of a close similarity, even identity, between painting and poetry, which became prevalent between the sixteenth and the eighteenth century. Walcott's poem, however, rejects simplistic formulations of identity and assumptions of unproblematic, immediate transposition between the so-called "sister arts" (often disguised attempts to uphold the superiority of poetry): as we have seen, it neither offers a description of the painting nor, for instance, resorts to the rhetorical technique of prosopopoeia (which, gives voice to "silent" paintings, often sustaining ekphrastic efforts). While the arrangements of the visual elements in Walcott's poem (tanker, tree, and heron) closely reproduce Doig's positioning of locomotive, bottle, and boat, restoring agency to Doig's "silent" painting, Walcott's "The Tanker" stages instead a compelling triangulation between great painting, beauty, and the absence of speech.

The beauty Walcott celebrates in "The Tanker" also defines what, for him, is the nature of "great" painting: "beauty" here is not an abstract, above-nature ideal that might require the mediation of declamation or (a) "speech" in order to become intelligible, but is to be found in the specific (and, crucially, seemingly mundane) Caribbean natural landscape he can see from his balcony. This landscape, the poem suggests, should be engaged with in silence and with a receptive mind-not overwhelmed, overdetermined, or distorted by the often disparaging or exoticizing rhetoric that has shaped, and has been shaped by, what Walcott identifies as the "wrong eye" with which the Caribbean landscape (but not only its landscape) has been traditionally approached (Walcott 1998:75). In order not to accost the Caribbean with the "wrong eye," Walcott here promotes what we can call the "right ear": in other words, if one needs to learn how to look at the Caribbean with fresh eyes, one needs to create the necessary silence to be able to tune in with what his friend Seamus Heaney has called "the music of what happens" (Heaney 1979:56). This "silence" is instrumental to overcoming a tradition of painting (or otherwise representing) the Caribbean that is governed by misapprehension and/or disfigurement, 
and countering what we can call a paradigm of ut pictura commentatio, which would presuppose an identity between painting and dominant discourses, often predicated on disabling "othering" practices.

Walcott has always considered as fundamental the act of creating this inner silence in order to properly attend to Caribbean soundscapes: in "The Castaway," he declares that to be able to "hear the polyp build" or the "silence thwanged by two waves of the sea" are important stepping stones for revolutionizing thinking and abandoning disabling "dead metaphors" (Walcott 1965:9). In Another Life, the child who puts a shell to his ear "hears everything / that the historian," distracted by imperial rhetoric and other dominant discourses, "cannot hear, the howls / of all the races that crossed the water" (Walcott 2009:143). In Morning, Paramin, Walcott reiterates this point on different occasions: in the poem "Baked," for example, he draws attention to the way in which, when the sun goes down in the Caribbean, one can still hear how "the frog dictates, the cricket starts to type" (Walcott \& Doig 2016:37). The poem is paired with a red and golden "weather" painting by Doig (Baked, 1990), which was inspired by the astonishingly and distressingly beautiful sunsets generated by the airborne toxic event in Don De Lillo's 1985 novel White Noise (Doig 201516). Walcott's poem wants us to hear frog and cricket so that we can also "hear" how they stand for a place (and a way of life) where such animals are still part of a sunset drama, and which, in the context of Doig's painting and De Lillo's novel, can be posited as an alternative to the self-destructive, profit-led (so-called) First World, which has historically depleted Walcott's Caribbean of natural resources, enslaved and indentured a great part of its population, and is now defacing its natural beauty, exploiting the locals, and threatening its culture and ecosystems: due to habitat loss, for example, a staggering 84 percent of amphibians in the Caribbean are threatened to become extinct. ${ }^{6}$

Another poem by Walcott, "Abstraction," makes a related point. "Abstraction" is in dialogue with Portrait (Under Water) (2007), a self-portrait where Doig appears isolated (or, indeed, abstracted) from the sounds that travel through the air, but fully exposed to the sounds traveling through the sea, which, according to Walcott, is both where Caribbean history ('The Sea is History,'Walcott 1979b) and the Caribbean itself are to be found: in a 1993 interview, in fact, Walcott openly declared that "the Caribbean is the sea."7 Looking at their paintings, Walcott argues, "we can hear what certain painters / heard as

6 Endangered Species International, http://www.endangeredspecies international.org/ amphibians4.html, accessed March 31, 2017.

7 Interview with Derek Walcott by Stuart Hall; see Derek Walcott: Poet of the Island, в вс Arena, January 2, 1993 . 
they worked" and, Walcott insists, Doig's ears are firmly attuned to the "brooding, breeding silence" of Trinidad's "deep bush" (Walcott \& Doig 2016:77). Taken together, therefore, "Abstraction" and Portrait (Under Water) establish a continuity between Caribbean/Trinidadian seascapes and landscapes, while the pairing of Walcott's poem "Milky Way" and Doig's Milky Way (1989-9o) instead connect starscapes and soundscapes. A Canadian starscape by Doig, in fact, becomes a springboard to create a Trinidadian soundscape that also celebrates the island's musical tradition as "maracas stars" provide the link between the musical instrument, Maracas (a location in the north coast of the island), and the stars of the Milky Way depicted by Doig (Walcott \& Doig 2016:21). In Trinidad, as Walcott suggests elsewhere in Morning, Paramin, some "people think that pain or pan is good for the soul" (Walcott \& Doig 2016:78): to "hear" Trinidadian music, therefore, also means to be able to attend to the pain of the people whilst appreciating the way in which they have turned that pain into an empowering tool of resistance.

Similarly, also the connection between great painting, beauty, and no speech put forward in "The Tanker," rather than promoting a disabling subordination of beauty to silence or a reinforcement of the traditional notion of pictures as dumb (Lessing 1776), seems to sustain an effort to tune in with the painting in order to celebrate local Caribbean reality (and counterdiscourses). Doig's painting might be untitled but it is not, strictly speaking, dumb: it does contain, in fact, the words "Stag" and "Lager Beer" on the beer bottle's label. "Stag" is the name of a Trinidadian beer, a reference that, once acknowledged, allows us to revisit the other objects in the painting by anchoring them, as the poem does for heron, tree, and tanker, to a Caribbean or, more precisely, Trinidadian reality. The friends in a boat are easily relatable to island life, but the same goes, perhaps surprisingly, for the nineteenth-century locomotive. Trinidad does not currently have a railway, but between 1876 and 1968 the Trinidad Government Railway developed a number of train lines that connected Port of Spain to the south and east of the island. Old locomotives of the Trinidad Government Railway similar to the one painted by Doig can be found immortalized in paintings, photographs, and stamps, and two are on display in Port of Spain and San Fernando. ${ }^{8}$ Arguably, as Walcott's poem and Doig's painting become one, they bring to the fore the importance, for an artist, of anchoring him/herself into his/her environment, of absorbing and be absorbed by its natural landscape, its silences, its sounds, its culture, its society, and its history.

8 Beadon 2014; Kautzor 2014; Public Transport Service Corporation Trinidad, http://www.ptsc .co.tt/about-us.html (accessed March 31, 2017). 
Trinidad, the island where Peter Doig and Walcott met for the first time, features prominently in the collection as both poet and painter have developed a strong and long-lasting bond with it. When he returned to Trinidad in 2000, Doig felt very welcome and realized that he had arrived in a very stimulating site for a painter: its sights, sounds, and smells (which he recognized from his childhood), its light and clashing colors, its contradictions, all contributed to make him decide to relocate to what he calls "a very special place" (Doig 2015-16; Scott 2007:24, 34; Werner 2013:30). Walcott, too, has always considered Trinidad inspirational: in his Nobel lecture, paying homage to the island's multiculturality — and upholding lack of "purity" as a desirable advantage — he has famously asserted: "I am only one-eighth the writer I might have been had I contained all the fragmented languages of Trinidad" (Walcott 1998:69).

In "Peter, I'm Glad You Asked Me Along," Walcott argues that Trinidad's "immense variety of racial choice," "all of its languages," its "music," "noise," and "craziness" are what make it dear to him and Doig: addressing the painter directly, Walcott concludes that Trinidad "is just where we belong" (Walcott \& Doig 2016:85). The painting by Doig that seemingly informs Walcott's conclusion, House of Flowers (See You There) (2007-9), encapsulates Doig's attraction to Trinidad's natural beauty and culture and the "craziness" Walcott talks about. Doig highlights the contrasts and continuities, assonances and dissonances in the rhythm of the composition, which set aside and, simultaneously, bring together, the two sides of the painting. On the left, straight green lines on a yellow wall make up differently sized bricks, which form a repeated geometrical pattern on which, in the lower section of the painting, black bricks with red contours are superimposed; on the right, the same black bricks are overlaid on a blue background; in the upper part of the painting, we see the curved, irregular lines of a black tree's branches, falling petals as differently sized and shaped white and pink dots, and green, curvaceous lines of hanging leaves that cover and disrupt the straight lines of the yellow wall whose regularity is being disturbed by petals blowing in the wind. The human figure in the middle, almost blending with the background, plays a decisive part in creating continuity between its right and left and its upper and lower sections: one can perceive black bricks under the thinly applied paint that constitutes his body, which is also covered by the petals falling from the tree; meanwhile his checkered trousers recall the colors (black, grey, and red) and shapes of the wall. The semitransparency of this chameleon-like figure provides a visual counterpart of what, in another poem, Walcott calls Doig's "clarity of moving with an open mind" (Walcott \& Doig 2016:99), an openness that allows one to absorb the world with enrichment and not dilution of one's identity — the figure retains his silhouette - and also embodies the poet's suggestion that, living in Trinidad, 
Doig might "pick up an accent" (Walcott \& Doig 2016:85) or, following Glissant, "extend" his identity.

This "clarity of moving with an open mind" also reverberates with what is promoted in the orchestrated dialogue between Walcott's "The Tanker" and Doig's untitled painting of a boat, a bottle of Stag, and a nineteenth-century locomotive, namely, the value of silence and a receptive attitude vis-à-vis the Caribbean landscape and Caribbean reality. The juxtaposition of House of Flowers and "Peter, I'm Glad You Asked Me Along"-a poem that, as we have seen, celebrates creolized and creolizing Trinidad-also exemplifies the nature of the collection's ekphrastic effort. This continuous process of creolization, according to Glissant, is what has made the Caribbean region "one of the places in the world where Relation presents itself most visibly" (Glissant 1997:33) by not aiming to erase what he calls the "real foundation of Relation" (Glissant 1997:189-9o), namely the "right to opacity" (many of the poems, as we have seen, do not even attempt to "describe" the painting). By fostering instead an alter/native form of collaboration and connectivity that embraces heterogeneity and mutual transformation, Morning, Paramin, one could argue, creolizes ekphrasis.

In Walcott's eyes, Doig's open-mindedness, his ability to hear and see the island with the right ear and eye, his deep love for the place, and his decision to return to Trinidad to live, all contribute to make the painter "native" rather than "foreign" (or, indeed, "other") to the world he is trying to depict: when someone "returns to what he loved in a landscape and stays there," Walcott argues, then this someone becomes not only "the lover of that particular part of earth" but also "a native" (Walcott 1998:77). Doig, however, does not take for granted his entitlement to paint Trinidad: most of his paintings, he has explained, "question" his "being there and also why things are as they are" (Doig, quoted in Aquin 2013:30). This questioning is sometimes directed toward the roots of the status quo, namely the island's colonial history, and in Walcott's ekphrasis of Relation, poems are shaped by and, at the same time, amplify Doig's visual questioning. Doig's Moruga (2002-8) is based on a photograph from a local newspaper reporting a re-enactments of the arrival of Christopher Columbus in Trinidad in 1498, when he is said to have named the island Trinidad. The newspaper's photographer captured the moment when a handful of actors pretending to be Spaniards, one of whom is brandishing a sword, are on a boat flying the flag of the Templars with its red cross on a white background and are about to land, with the sea around them perfectly calm and the horizon open (Werner 2013:26). In Doig's painting, instead, the landing is taking place in a bay framed by green/blue and brown hills and what appears to be elaborate dark-brown foliage hanging from above; the sea is purple/brown, apart from a 
fiery orange/yellow strip, and the golden/white sky is partially obscured by the foliage. As a result, Doig's painted scene is much darker and more foreboding, as if to highlight that the arrival of Europeans on the Trinidadian coast was the prelude of genocide, colonialism, slavery, and indentureship, and to signpost, perhaps, Doig's awareness that Discovery Day was abolished in Trinidad in 1985 to be substituted by Emancipation Day (Doig 2015-16).

In Walcott's "Moruga," one of the most straightforward verbal "representations" of a painting to be found in the collection, we are informed that what Doig has painted is in fact a re-enactment of the "myth" of discovery, a myth which, like the performance it has been inspired by, "has been thoroughly rehearsed"; going as far as saying that Columbus never set foot on Trinidad, Walcott asserts that Doig paints his arrival "for what it is: a fable" (Walcott \& Doig 2016:19). The poetics of Relation that governs this particular dialogue between poem and painting, therefore, stretches this verbal representation of visual representation (or the poem's "aboutness" in relation to the painting) to include and confront, head-on, discourses and counterdiscourses surrounding the "discovery" of America: this "fable," the poem continues, is about the "curse" of colonialism or the "virtuous practice" of the spreading of Christianity, depending on how one decides to (re)write history (Walcott \& Doig 2016:19).

Walcott's "10o Years Ago (Carrera)" is also concerned with seafaring, history, and colonialism, as testified by his references to Samuel Taylor Coleridge's The Ancient Mariner from 1798 and Ben Gunn from Robert Louis Stevenson's novel Treasure Island originally published in $1883 .{ }^{9}$ The poem responds to Doig's 100 Years Ago (Carrera) (2001) and the implicit invitation to revisit the past inherent in the painting's title. As a solitary and emaciated man looks at us from an impossibly long canoe, which cuts the painting in two horizontally, we are faced with the only prose poem of the collection whose very long lines mirror the length of Doig's canoe: incidentally, by drawing our attention to the fact that writing itself-in the sense of the words as they are printed on the pageis a visual as well as a verbal reality, the poem questions the very existence of rigid boundaries between visual and verbal and highlights, once again, how the visual has influenced the formal composition of the poem, restoring a form of agency to both painter and painting.

The source for Doig's painting is a photograph of the 1970s Allman Brothers Band (Grenier 2007:107) that portrays all the five members of the band, not just the late Berry Oakley, who is the one who has inspired the painter: as this

9 Walcott actually mentions Kidnapped (1886), another novel by Stevenson, in which adventures at seas play an important part. 
iconic figure reminds us of the 1970s, the title of the painting (10o Years Ago) directs us instead to the beginning of the twentieth century, which Catherine Grenier identifies with what she calls "the primal territories of modern times: Romanticism, Realism, and Symbolism” (Grenier 2007:113). Yet, by recasting the canoe as a "hyphen between centuries, / between generations, between trees"-highlighting again the continuity between painted shapes ("canoe") and graphic signs ("hyphen") - the poem invites us to revisit an even more remote past and another moment that has often been saluted as the beginning of modernity, namely the encounter between European powers and the indigenous population in the Caribbean (Walcott \& Doig 2016:17). The craft of building canoes from trees, which Walcott (1990:3-5) also praises in Omeros, is in fact a practice that goes back to the indigenous inhabitants of the Caribbean who were massacred as a result of colonialism, but who also coined the word canoe and whose lingering presence we can "hear" in the word and "see" in its corresponding image.

The poem also draws our attention to the fact that behind the figure in Doig's painting lurks the island of Carrera, mentioned in the parenthetical title. As Walcott explains, Carrera is one of the islands of the Gulf of Paria, which, far from being a "treasure" island, has been used as a prison since 1854. Doig has revealed that he added Carrera to a painting of the man in the canoe after his first visit to Trinidad in the year 2000 when, during a boat trip, he discovered what the island was being used for; he felt uncomfortable looking at it, partly because it (deceptively) looks like a very "exotic" villa (Doig 2015-16). ${ }^{10}$ The title contains no clue as to what the island actually is, but if the inclusion of Carrera alters the painting's composition by giving us another focal point, it also complicates our relationship with the painting itself, as the man's gaze is directed at and interrogates us while we are looking at him and the island. Revealing what Carrera stands for, therefore, the poem forces us to partake of Doig's discomfort while looking at the painting, urging us to question our assumptions of what constitutes a Caribbean landscape or a Caribbean island; to ponder on the continuities (or "hyphens") that connect slavery and imprisonment, tourism and colonialism; and to reconsider, with the painter, the different ways in which we might be implicated in all this.

Carrera returns in another painting in which Doig addresses the issue of landscaping Trinidad more directly, namely House of Pictures (Carrera) (2004),

10 In the Montreal exhibition, Walcott was able to see also a version of this painting without the island called 100 Years Ago (2002), which also appears in the catalogue with other versions (Werner 2013:63-65). 
where on a colorful brick wall hang four paintings of - or four windows onwhat might have been the actual view the wall is obstructing: two thirds of each of these paintings are dark blue (the sea), while the remaining third is light blue (the sky). Carrera sits on the horizon of two of the paintings, cut in two vertically. Above the wall is the sky, while under the wall is a grey pavement with some weeds and a broken bottle of Stag that Doig decided to include as a "random act of violence" (Doig 2015-16). Historically, landscaping the Caribbean amounted to leaving (mostly slavery-related) acts of violence and unpleasant views out of the frame: here Doig urges us to rethink these falsifying paradigms by bringing Carrera into the frame of the paintings/windows and making it rhyme with the broken bottle inside the frame of his own painting, pressing us (and himself) to look again without "overlooking the gritty present-day reality of the island" (Hartley 2013:72) or, indeed, its troubled past. Walcott's "House of Pictures (Carrera)" arrives at a similar conclusion through a different route, which further localizes poem and painting. Doig's brick wall, Walcott insists, is the artist's homage to local craftsmen (more specifically, masons who build walls similar to the one we are facing in the painting). As the poem celebrates the work of all those who humbly and stubbornly "take care to fit the cut stone into its wall," we are invited to see the painter's decision to include Carrera and the broken bottle in his landscape (unmentioned in the poem but clearly visible in the painting) as Doig's way to "fit" his "stone/image" in the bigger "picture/wall" of Trinidadian past and present (often unpalatable) reality (Walcott \& Doig 2016:89).

In Metropolitain (House of Pictures) (2004), a nineteenth-century figure is caught in the act of looking at a display of paintings in Doig's adaptation of Honoré Daumier's The Print Collector (1857-63). Unlike the print collector in Daumier's work, Doig's collector is confronted mainly by empty frames, but one can still perceive, faintly, one of the versions of a painting by Doig in which a man holds a dead pelican by its neck on a beach. ${ }^{11}$ Initially, all the paintings on display were Doig's own tropical landscapes, but these were subsequently scrubbed out by the painter himself: both this act of self-erasure and the fact that the collector's backdrop is an abstract rendition of the view out of Doig's studio window (Scott 2007:34) signpost Doig's questioning, once

11 Pelican Man (2003) is included in Morning, Paramin juxtaposed to a poem that denounces Caribbean environmental degradation. The painting Pelican Man (2003) was not in Montreal, but appears in the catalog of the exhibition together with Pelican (Night) (2004) (also not exhibited) and many other versions-Pelican (Stag) (2003), Pelican (2003), Pelican (2004), Halterback (2004), Pelican (2002), Fisherman (2002) — which were on display in Montreal (Werner 2013:118, 119, 121, 122, 123). 
again, his right and his ability, as a metropolitan outsider, to do justice to the powerful landscape of Trinidad. Walcott's "Metropolitain (House of Pictures)" acknowledges Doig's source and describes the collector as Daumier's flâneur, but, in the context of Morning, Paramin, the melancholic demeanor of the flâneur might also reflect an ekphrastic poet's anxiety regarding his abilities to respond adequately to the paintings he is drawn to. The flâneur, Walcott writes, is saddened by the fact that he cannot afford to buy one of the works that he is admiring, and the painting depicts the "distance of the heart / from what it cannot own" (Walcott \& Doig 2016:73). Arguably, it is precisely this desire to own - or fully grasp or explain (away) - a painting (or a landscape) that the flâneur, but also the painter and ekphrastic poet, needs to reconfigure. Morning, Paramin, as we have seen, is driven by and foregrounds a different impulse: the impulse not to appropriate and own, but to love and honor both the paintings that the poems are engaging with and the worlds and realities they represent and, ultimately, "are." Discarding the paragonal struggle for dominance or a comparativist approach that presupposes total transparency and translatability between the two arts, the dialogue between poems and paintings establishes, and is shaped by, a poetics of Relation that renounces ownership or "com-prehension" in the etymological, appropriative, predatory, and repressive way in which Glissant understands the word (from the French comprendre, con "with" and prendere "to take") and upholds instead the transformative generosity of perception and openmindedness that the Martiniquan theorist names, with an arresting inversion, donner-avec or give-on-and-with (Glissant 1997:23-35; Wing 1997: xiv, italics in the text).

In "Grande Riviere I," Walcott responds to (or gives-on-and-with) Doig's landscape painting Grande Riviere (2001-2), based on a photograph taken on the north east side of Trinidad (Werner 2013:106). The painting portrays a white horse on a river shore surrounded by black birds; the scene takes place at night and the brightness of stars is reflected in the water's surface. Bringing words and images together, the poem refers to alternative renderings of "exotic" places: conjuring up Captain Marryat and Joseph Conrad alongside covers of Victorian novels where the "green of the forest drips to devour the explorer," Walcott goes to the (imperial) root of what he calls the "wrong eye," Glissant's com-prehension, and Doig's self-questioning, showing how cultural lenses can (mis)construe as menacing the "lowering green emptiness" that Walcott loves "as hard as Peter Doig" and finds so admirably portrayed in his work (Walcott \& Doig 2016:49). In another version of the same painting, Grande Riviere (2002), the horse and the birds occupy center stage, but their shapes are only roughly sketched, as if they were part of a faintly remembered, nightmarish landscape. 
Walcott's poem facing this painting, "Grande Riviere II The Phantom Steed," is a monologue by an explorer who recounts a journey down a river during which he saw a white horse he "immediately wanted" for himself because, he claims, "ours / was a just conquest, just murder and just greed" (Walcott \& Doig 2016:51). In this critique of imperial rhetorical deception, Walcott shows how the threat posed by the conqueror to the place he is about to conquer is ultimately projected onto the endangered landscape, which is rendered as ominous, foreboding, terrifying: despite feeling his "claim / to be inevitable," when he tries to get closer to the steed, the explorer realizes, with "Terror," that it "was gone" and that only menacing vultures were "waiting in the shifting sun" (Walcott \& Doig 2016:51)..$^{2}$

It is also possible, of course, to interpret the poem as another meditation on the relationship between paintings, poems, and their subjects: as the explorer is drawn to the horse like a painter or poet might be drawn to his/her subject (or a poet engaging with paintings, to a painting), the explorer's desire (like the collector's in the previous example) is distorted by a greed and a will to possess, which refuse to acknowledge the landscape or the horse as real, living presences. These presences, instead, demand and deserve to be reckoned with: as Glissant would have it, one needs to tune in, yield to, and give-on-andwith rather than grasp, com-prehend, or own them (Glissant 1997:23-35; Wing 1997:xiv; italics in the text). Significantly, when questioned about the black birds in Grand Riviere and what the interviewer described as their "ominous" relationship with the white horse, Doig refuted any gloomy intimation: "where my house is in Trinidad, there are a lot of these birds flying around ... I painted them really just because I drew them and I drew them because they were just there" (Doig, quoted in Cook 2013:180).

A huge black bird returns in the last painting in the collection, Cave Boat Bird Painting (2010-12), in which it flies over a boat containing a sleeping fisherman wearing a pink hat that covers his eyes and nose. In the poem opposite to it, Walcott recounts his (failed) attempts at bird-watching, acknowledging the elusive nature of birds, their indifference to the beholder, their stubborn "open life" as well as their surprising, sudden deaths, or the fact that, in other words, they live according to their own rhythm (Walcott \& Doig 2016:103). Walcott also re-imagines Doig's painting as a self-portrait and pays tribute to the painter-sleeping-fisherman who has become part of the Trinidadian seascape,

12 In the Montreal exhibition, Walcott could also see another (more "ghostly") version, Grande Riviere (2002), with just a rather abstract silhouette of the horse's head (Werner 2013:106). 
no longer just a "native" who paints the island, but "one of those things / that a corbeau passes or the hawk with its gold eye" (Walcott \& Doig 2016:103). As the painter becomes the object of the gaze of some of his former subjects, the relation between him and the natural landscape becomes a communion (or Relation) where subjects and objects occupy interchangeable positions, as, in a way, do the poems and paintings in the collection: once they are read and looked at together, they combine and recombine in novel ways, making it impossible and, indeed, irrelevant, to establish which one is the subject or object of the other.

Overall, therefore, Morning, Paramin explores and brings to the fore the many possibilities inherent in a creative collaboration that can only result from the clarity of an open-mind: the cover of the volume, after all, posits Walcott and Doig as co-authors, even if, chronologically, Doig's paintings were produced before he met Walcott and Walcott is ultimately responsible for the orchestration of poems and paintings. Walcott and Doig, however, share the authorship of a collection that is not shaped by what Mitchell has categorized as "ekphrastic fear," "ekphrastic indifference," or "ekphrastic hope" (Mitchell 1994:151-56), but by an ekphrasis of Relation in which the verbal and the visual interact in complex ways, often exercising a mutual reclaiming of agency. In Morning, Paramin, in fact, poems and paintings establish a dialogue that is not only mutually transformative, but also engenders new composite works of art governed by a noncompetitive, nonexploitative, nonpredatory approach, which reconfigures otherness, does not try to deny individuality or opacity, and in which each image and each word, while "breathing" according to their own rhythm, "cohere" and "finally ignite," as Walcott had put it in Another Life (2009:58-59), contributing to a whole that is considerably bigger that the sum of its parts.

\section{References}

Abramowitz, Janet N., 2001. Unnatural Disasters. Washington DC: Worldwatch Institute. [Worldwatch Paper 158.]

Aquin, Stéphane, 2013. No Land Foreign to Painting. In Michael Werner(ed.), Peter Doig: No Foreign Lands. Ostfielden, Germany: Hatje Cantz Verlag, pp. 8-51.

Ashbery, John, 1985. Selected Poems. New York: Viking Penguin.

Beadon, Glen, 2014. Real Story of Engine D. Sunday Express, December 16. http://www .trinidadexpress.com/news/Real-story-of-Engine-D-285931141.html.

Benjamin, Walter, 1999. The Work of Art in the Age of Mechanical Reproduction. In Walter Benjamin, Illuminations. London: Pimlico, pp. 211-44. [Orig. 1936.] 
Cheeke, Stephen, 2008. Writing for Art: The Aesthetic of Ekphrasis. Manchester: Manchester University Press.

Colerdige, Samuel Taylor, 2014. The Rime of the Ancient Mariner. London: Vintage Classics. [Orig. 1798.]

Cook, Angus, 2013. Peter Doig in Conversation with Angus Cook. In Michael Werner (ed.), Peter Doig: No Foreign Lands. Ostfielden, Germany: Hatje Cantz Verlag, pp. 15693 .

Doig, Peter, 2007. Peter Doig: Twenty Questions (an extract), 2001. In Adrian Searle, Kitty Scott \& Catherine Grenier (eds.), Peter Doig. London: Phaidon, pp. 124-41.

Doig, Peter, 2015-16. Slade Contemporary Art Lecture Series-Peter Doig. https://www .youtube.com/watch?v=Xs8pTMXPAPc.

Döring, Tobias, 2002. Caribbean-English Passages: Intertexuality in a Postcolonial Tradition. London: Routledge.

Emery, Mary Lou, 2007. Modernism, the Visual and Caribbean Literature. Cambridge: Cambridge University Press.

Glissant, Édouard, 1997. Poetics of Relation, trans. by Betsy Wing. Ann Arbor: University of Michigan Press. [Orig. Poétique de la Relation, 199o.]

Grenier, Catherine, 2007. Reconquering the World: 100 Years Ago. In Adrian Searle, Kitty Scott \& Catherine Grenier (eds.), Peter Doig. London: Phaidon, pp. 105-13.

Hagstrum, Jean, 1958. The Sister Arts: The Tradition of Literary Pictorialism and English Poetry from Dryden to Gray. Chicago: University of Chicago Press.

Hamner, Robert, 200o. From Winslow Homer to Marcel Duchamp and the Fortunate Flaw in Derek Walcott's Omeros. ARIE L: A Review of International English Literature 31(3):75-103.

Handley, George, 2010. New World Poetics: Nature and the Adamic Imagination of Whitman, Neruda, and Walcott. Athens: University of Georgia Press.

Hartley, Keith, 2013. A Visual Intelligence. In Peter Doig: No Foreign Lands. In Michael Werner (ed.), Peter Doig: No Foreign Lands. Ostfielden, Germany: Hatje Cantz Verlag, pp. $5^{2-155}$.

Heaney, Seamus, 1979. Field Work. New York: Farrar, Straus and Giroux.

Heffernan, James A.W., 1993. Museum of Words: The Poetics of Ekphrasis from Homer to Ashbery. Chicago: University of Chicago Press.

Hollander, John, 1995. The Gazer's Spirit: Poems Speaking to Silent Works of Art. Chicago: Chicago University Press.

Hudson, Mark, 2013. Peter Doig Interview: The Triumph of Painting. The Telegraph, August 2. http://www.telegraph.co.uk/culture/art/10216288/Peter-Doig-interview -the-triumph-of-painting.html.

Jelly-Shapiro, Joshua, 2107. A Trinidadian Friendship: Derek Walcott and Peter Doig. New Yorker, January 12. http://www.newyorker.com/books/page-turner/a -trinidadian-friendship-derek-walcott-and-peter-doig. 
Kautzor, Thomas, 2014. The Railways of Trinidad. http://www.internationalsteam.co.uk/ trains/trinidador.htm.

Keefe, Anna, 2011. The Ecstatic Embrace of Verbal and Visual: Twenty-First Century Lyric Beyond the Ekphrastic Paragone. Word \& Image 27(2):135-47.

Krieger, Murray, 1967. Ekphrasis: The Illusion of the Natural Sign. Baltimore MD: Johns Hopkins University Press.

Lessing, Gotthold Ephraim, 1887. Laocoon: An essay upon the limits of painting and poetry. With remarks illustrative of various points in the history of ancient art, trans. by Ellen Frothingham. Boston MA: Roberts Brothers. [Orig. 1776.]

Mitchell, W.J.T, 1986. Iconology: Image, Text, Ideology. Chicago: University of Chicago Press.

Mitchell, W.J.T, 1994. Picture Theory: Essays on Verbal and Visual Representation. Chicago: University of Chicago Press.

Mitchell, W.J.T, 2005. What do Pictures Want: The Lives and Loves of Images. Chicago: University of Chicago Press.

Neumann, Birgit, 2016. Postcolonial Ekphrasis and Counter-Visions in Derek Walcott's Tiepolo's Hound - Contacts, Contests and Translations. Zeitschrift fur Anglistik und Amerikanistik 64(4):447-65.

Price, Sally \& Richard Price, 20o6. Romare Bearden: The Caribbean Dimension. Philadelphia: University of Pennsylvania Press.

Rippl, Gabriele, 2010. English Literature and Its Other: Towards a Poetic of Intermediality. In Christian Emden \& Gabriele Rippl (eds.), ImageScape: Studies in Intermediality. Oxford: Peter Lang, pp. 39-65.

Scott, Kitty, 2007. Kitty Scott in Conversation with Peter Doig. In Adrian Searle, Kitty Scott \& Catherine Grenier (eds.), Peter Doig. London: Phaidon, pp. 7-49.

Searle, Adrian, Kitty Scott \& Catherine Grenier (eds.), 2007. Peter Doig. London: Phaidon.

Oxford Classical Dictionary, 1968. The Oxford Classical Dictionary. Oxford: Clarendon Press.

Stevenson, Robert Louis, 200o. Treasure Island. London: Penguin Classics. [Orig. 1883.]

Stevenson, Robert Louis, 2007. Kidnapped. London: Penguin Classics. [Orig. 1886.]

Thompson, Krista A., 2006. An Eye for the Tropics: Tourism, Photography, and Framing the Caribbean Picturesque. Durham NC: Duke University Press.

Udika, Rudo, 2010. Flood Management: An Examination of Mitigation Measures for Flooding in Urban Areas in Trinidad. 46th ISOCARP Congress. www.isocarp.net/ Data/case_studies/1758.pdf.

Walcott, Derek, 1965. The Castaway and Other Poems. London: Jonathan Cape.

Walcott, Derek, 1979a. The Joker of Seville \& O Babylon! London: Jonathan Cape. [Orig. 1978.]

Walcott, Derek, 1979b. The Star-Apple Kingdom. New York: Farrar, Straus and Giroux. 
Walcott, Derek, 1986. The Last Carnival. Three Plays: The Last Carnival; Beef, No Chicken; A Branch of the Blue Nile. New York: Farrar, Straus and Giroux.

Walcott, Derek, 199o. Omeros. London: Faber and Faber.

Walcott, Derek, 1998. What the Twilight Says: Essays. London: Faber and Faber. [Orig. 1993.]

Walcott, Derek, 200o. Tiepolo's Hound. New York: Farrar, Straus and Giroux

Walcott, Derek, 2002. Walker and The Ghost Dance. New York: Farrar, Straus and Giroux.

Walcott, Derek, 2009. Another Life. In Edward Baugh \& Colbert Nepaulsingh (eds.), Another Life: Fully Annotated. Boulder CO: Lynne Rienner, pp. 1-152. [Orig. 1973.]

Walcott, Derek, 2012. Moon-Child. New York: Farrar, Straus and Giroux.

Walcott, Derek, 2014. O Starry Starry Night. New York: Farrar, Straus and Giroux.

Walcott, Derek \& Romare Bearden, 1983. The Caribbean Poetry of Derek Walcott and the Art of Romare Bearden. New York: The Limited Editions Club.

Walcott, Derek \& Francesco Clemente, 2009. A History of the Heart in Three Rainbows. Milano: Edizioni Charta.

Walcott, Derek \& Peter Doig, 2016. Morning, Paramin. New York: Farrar, Straus and Giroux.

Werner, Michael (ed.), 2013. Peter Doig: No Foreign Lands. Ostfielden, Germany: Hatje Cantz Verlag

Wing, Betsy, 1997. Translator's Introduction. In Édouard Glissant, Poetics of Relation, trans. by Betsy Wing. Ann Arbor: University of Michigan Press, pp. xi-xx. 